\title{
9. Piecing the History Together: An overview of the 1948 Arnhem Land Expedition
}

\author{
Sally K. May
}

Friday, 2 February 1945 was a defining day in the life of Charles Mountford. The South Australian ethnographer stood nervously in front of a room packed to capacity with enthusiastic members of the National Geographic Society. They had come to be entertained with stories of the exotic Indigenous people of Australia by the adventurer who had 'captured' them in photographs and moving pictures. A handful of people in the audience that day had the power to further Mountford's ethnological collecting and research ambitions. Members of the National Geographic Society Research Committee approached Mountford and suggested he submit a proposal for a scientific research expedition. ${ }^{1}$ This suggestion sparked the beginning of a planning process that culminated in a seven-month journey across the Northern Territory of Australia. The story behind the negotiations, preparations and final realisation of this Expedition is important for our understanding of its legacy, and it is clear that politics, propaganda and science became uneasy bedfellows for the 1948 AmericanAustralian Scientific Expedition to Arnhem Land.

After 10 years of researching the Arnhem Land Expedition, I feel like an octogenarian trying to populate their family tree but finding that with each new person comes another 40 lines of possible investigation. The Arnhem Land Expedition is a never-ending, interwoven tree of people, places and events. ABC journalist Colin Simpson's much quoted reflection on the importance of this Expedition sums up the scale of the task. He states, 'What it accomplished is said to have been scientifically considerable, but is not measurable now, and perhaps never will be. Such findings take years to write and codify and publish and disseminate. When that is completed, the use of them is only at the beginning. ${ }^{2}$ When Simpson wrote these words in 1951 he obviously suspected that more than half a century later we would still be writing, codifying, publishing and disseminating the findings of their work.

1 Mountford, C. 1975, 'Report on expedition for the National Geographic Society', Great Adventures with National Geographic, National Geographic Society, Washington, DC, p. 225; Mountford, C. P. (ed.) 1956, Records of the American-Australian Scientific Expedition to Arnhem Land. Volume 1: Art, myth and symbolism, Melbourne University Press, Carlton, Vic., p. ix.

2 Simpson, C. 1951, Adam in Ochre: Inside Aboriginal Australia, Angus \& Robertson, Sydney, p. 40. 
In spite of that, while the collections are the tangible result of the Arnhem Land Expedition, they are not the only reason for its lasting, and perhaps increasing, significance. Interest in this Expedition comes from a much wider group than just museum workers and academics, and includes Indigenous Australians, descendants of the men and women who participated in the Expedition, members of the general public who grew up reading Mountford's popular books or seeing his films, the mums and dads who remember reading the latest update on the Expedition in newspapers throughout 1948, and much, much more. Our true understanding of the significance of this Expedition for many stakeholders is only just beginning to emerge.

In February 1948, a team of Australians and Americans came together in Darwin, Australia, to begin what was then one of the largest scientific expeditions ever to have taken place in this country. They travelled across Arnhem Land until November 1948, basing their work around three key Indigenous communities: Groote Eylandt, Yirrkala and Oenpelli (today Gunbalanya) (Figure 9.1). Before I go into more detail about the base camps and the nature of the research it is important to understand a little more of the origins of the Expedition and the people and organisations at the forefront of the planning.

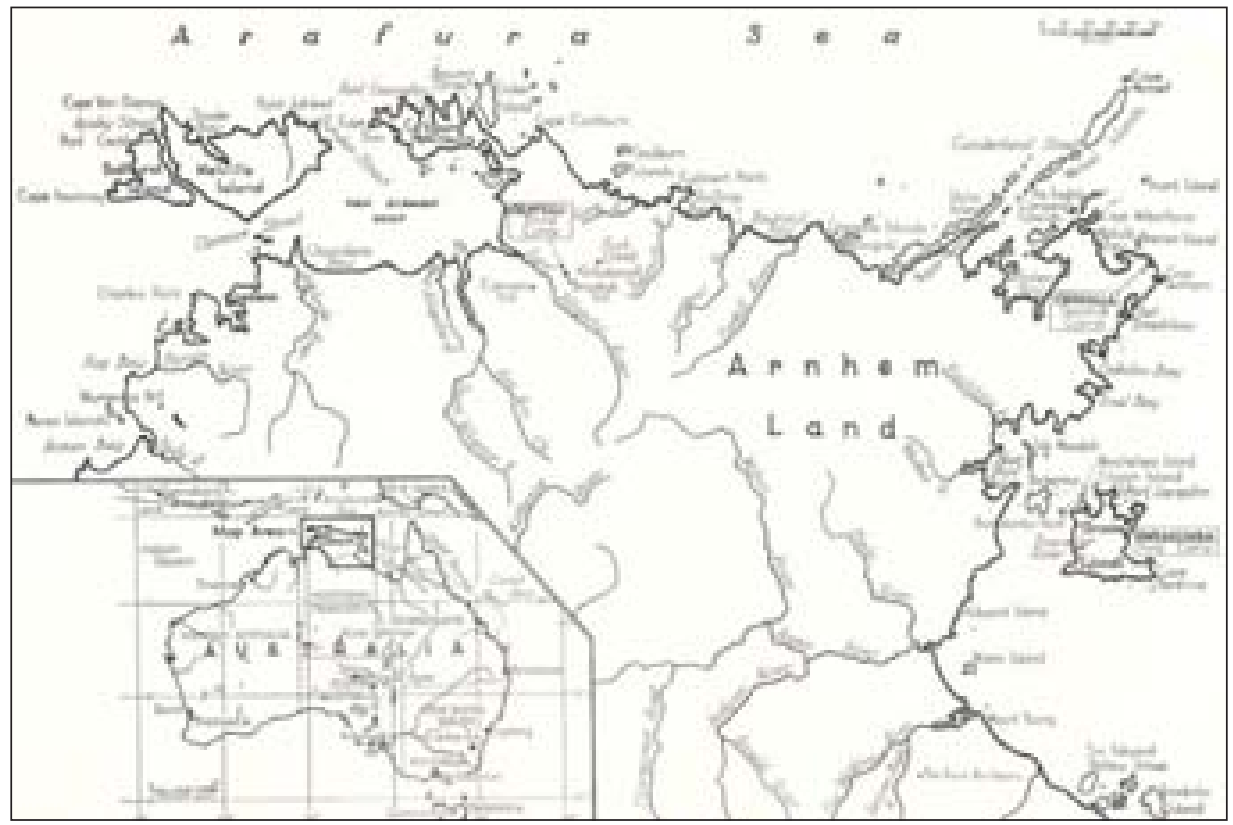

Figure 9.1 Map of the Northern Territory, Australia, showing regions visited during the 1948 Arnhem Land Expedition

From Charles P. Mountford (ed.) 1956, Records of the American-Australian Scientific Expedition to Arnhem Land. Volume 1: Art, myth and symbolism, Melbourne University Press, Carlton, Vic. 
While on the surface the pursuit of science and knowledge would seem to be the key motivator for the Arnhem Land Expedition, in truth politics was central to its success in attaining funding and international collaborators. This can be better understood by looking at the leader of the Expedition and his work promoting and planning the Expedition prior to 1948 (Figure 9.2). Charles Mountford was born in 1890 to a family with Scottish and English heritage. Most of his family were farmers or general labourers who lived in South Australia. Mountford insisted to his biographer, Max Lamshed, that his family was 'poor, but it was a uniform poverty. Everyone was in the same boat, so we didn't notice. ${ }^{3}$ In his early life, Mountford lived in Adelaide working in jobs such as a stereoscope salesman, stable boy, blacksmith's striker, and tram conductor. By the age of twenty, he was undertaking a course in mechanics and engineering, which helped him to secure a position with the engineering department of the postal service. He married in 1914, and was posted to Darwin in 1920 as the mechanic in charge at the Darwin Post Office. ${ }^{4}$ It was in Darwin that Mountford's interest in Indigenous Australian cultures is thought to have begun. ${ }^{5}$

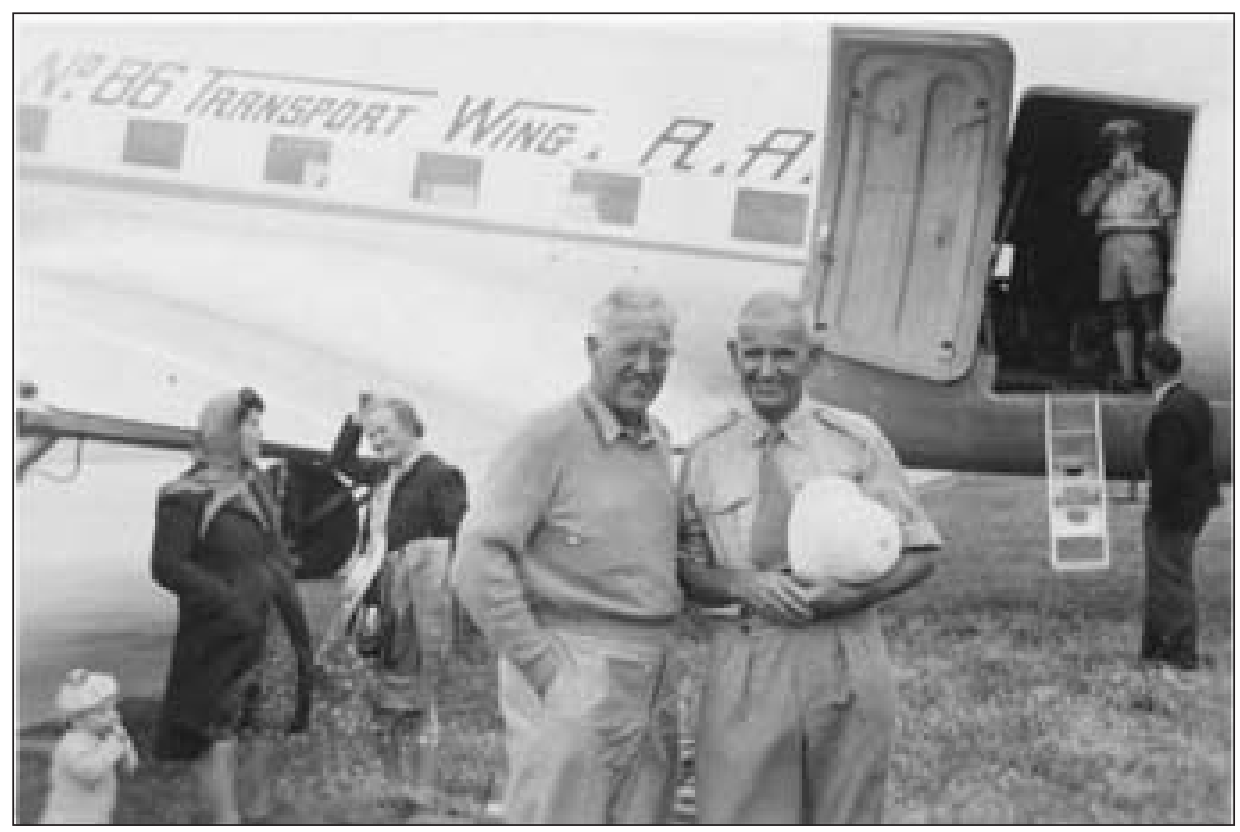

Figure 9.2 Charles Mountford and Frank Setzler in Adelaide, 17 November 1948

By permission of the National Library of Australia. nla.pic-an24313084.

3 Lamshed, M. 1972, Monty: A biography of C. P. Mountford, Rigby, Adelaide, p. 10.

4 Ibid, p. 10.

5 May, S. K. 2009, Collecting Cultures: Myth, politics, and collaboration in the 1948 Arnhem Land Expedition, Altamira, Calif., p. 37. 
After returning to Adelaide in 1922-23, and the death of his wife in 1925, Mountford took to travelling around South Australia with his father. They came across many Indigenous rock art sites during these adventures and made contact with Norman Tindale at the South Australian Museum to discuss their findings. Tindale, and others such as J. B. Cleland and T. D. Campbell, encouraged Mountford to continue exploring and documenting sites. Mountford participated in three anthropological research expeditions to Central Australia during the 1930s, with the assistance of these colleagues. This period is discussed in detail by Philip Jones, but it is important to note that by 1948 Mountford had attained certain knowledge relating to Indigenous art and, in particular, the Pitjantjatjara, Adnjamatana and Arrernte people. ${ }^{6}$ He had produced short films including Tjurunga (1942) and Walkabout (1942), and collected and documented ethnographic artefacts, rock art sites and cultural stories from Indigenous communities in South Australia. ${ }^{7}$ These films were what caught the attention of the then Federal Minister of Information, Arthur Calwell. This now notorious politician saw the potential of these films for international publicity for Australia. ${ }^{8}$ Mountford was offered a position in Calwell's Department of Information and sent on a lecture tour to promote Australia in the United States. ${ }^{9}$

As mentioned earlier, Mountford was awarded funding for a new expedition to Arnhem Land. ${ }^{10}$ His proposal to the National Geographic Society outlines his intentions and, in particular, his desire to record and collect Australian Indigenous art. He states: 'Knowing that the simple art of these people would be the first aspect of their culture to disappear, I have concentrated on the investigation and recording of all phases of their art.' ${ }^{11}$ He goes on to claim that his previous work in Central Australia 'has saved the art of the Central Australian from extinction'. ${ }^{12}$ The official 1945 research proposal submitted by Mountford ${ }^{13}$ includes study of four main areas: a) the art of the bark paintings; b) the art of the body paintings; c) the general ethnology of the people; and d) music in secular and ceremonial life. Yet, there were also unpublicised aims for this Expedition. These aims were outlined 18 months later in a private letter from Mountford to the President of the National Geographic Society, Gilbert Grosvenor: ${ }^{14}$

6 Jones, this volume.

7 May, Collecting Cultures.

8 Arthur Calwell is remembered for championing the White Australia Policy.

9 Mountford, 'Report on expedition for the National Geographic Society', p. 225; Mountford, Records of the American-Australian Scientific Expedition to Arnhem Land, vol. 1, p. ix.

10 L. J. Briggs, 20 April 1945, Letter to G. Grosvenor, Accession file 178294, Smithsonian Institution Archives, Washington, DC.

11 Charles Mountford, 5 March 1945, Letter to the Chairman of the National Geographic Society Research Committee, Accession File 178294, Smithsonian Institution Archives, Washington, DC, p. 2.

12 Ibid.

13 Ibid

14 Charles Mountford, 28 January 1947, Letter to Gilbert Grosvenor, Setzler Files, Box 7, Folder 4, Arnhem Land Correspondence 1948-1949, Folder 1 of 2, National Anthropological Archives, Washington, DC. 
1. Establish a good neighbour policy and scientific cooperation between the United States of America and Australia.

2. Provide publicity for Australia through the publication of three, if not four, illustrated articles in the National Geographic Magazine. (Circulation 1,250,000. Estimated Readers 5,000,000).

3. Study and record the aborigine's pattern of life in relation to the terrestrial and marine fauna and flora.

4. Investigate seasonal movements and shelter of the aborigines, and, by examination of their foods determine how well, or otherwise, they are able [to] 'live off the land'.

5. Make a nutritional health survey of the natives and their food as a guide for future administration.

6. Collect and identify the plants, birds, animals and fish in the various environments of Arnhem Land.

7. Carry out a food fish survey along the coast of Arnhem Land.

8. Determine the food resources of land and sea as data for future military operations [this was urgently needed, but not available, during the previous war].

9. Produce, for the National Film Board, five coloured cine films on the ethnology and natural history of Arnhem Land.

International politics and propaganda were just as important (if not more important) as science for the Arnhem Land Expedition.

Calwell is today recognised for the role he played in the Arnhem Land Expedition; it could not have occurred without his backing. He saw the National Geographic Society's funding of an expedition as a wonderful opportunity for promoting political and scientific relations between Australia and the United States. Calwell arranged for the Commonwealth Government to pay Mountford his usual wage plus expenses for the Expedition and transport. ${ }^{15}$ The Ministers for Air, the Army and Health all offered support including transport, food, and, importantly, three scientists from the Australian Institute of Anatomy were allowed to join the Expedition and study Indigenous health and nutrition (Figure 9.3). The Minister for the Interior also placed his organisation in the Northern Territory at their disposal. ${ }^{16}$

15 Mountford, Letter to the Chairman of the National Geographic Society Research Committee, p. 4.

16 Mountford, Records of the American-Australian Scientific Expedition to Arnhem Land, vol. 1, p. xxi. 


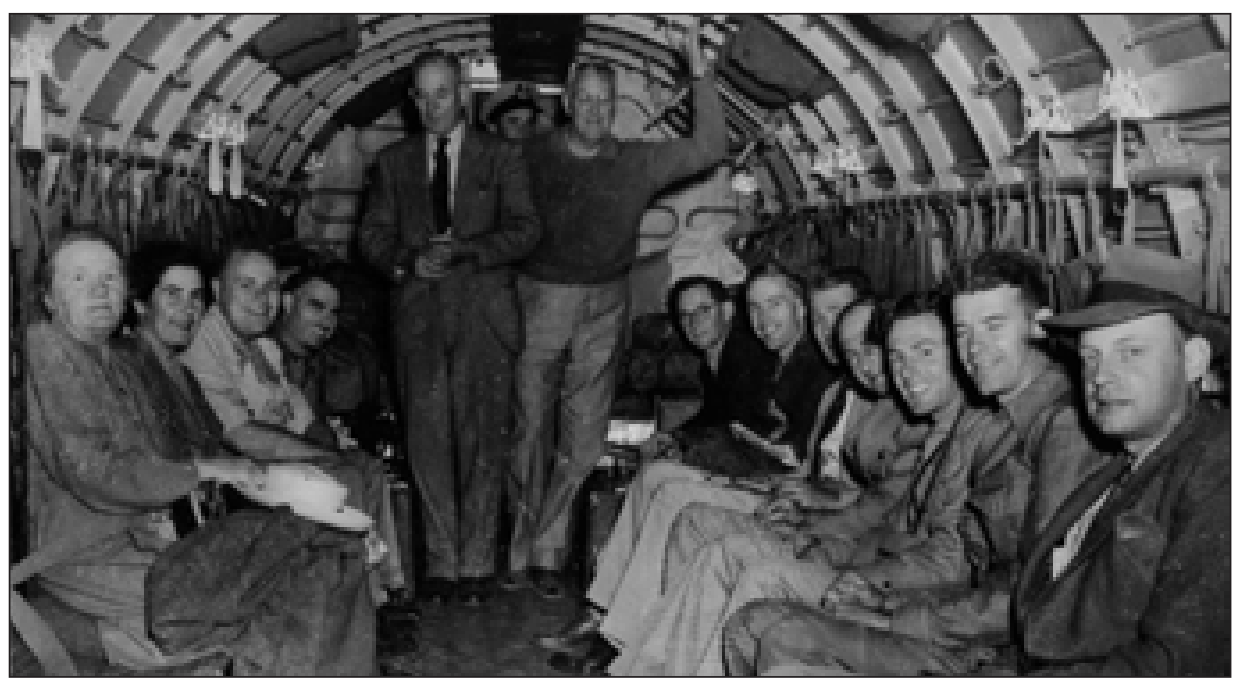

Figure 9.3 Expedition members aboard flight from Adelaide to Darwinleft: Bessie Mountford, Margaret McArthur, Brian Billington, Peter Bassett-Smith, Charles Mountford (standing), Frank Setzler (standing). Right: Frederick McCarthy, Kelvin Hodges, Herbert Deignan, John Bray, Raymond Specht, Bob Miller, Dave Johnson, March 1948

By permisison of Raymond Specht.

Arthur Calwell was responsible for the massive expansion of the Arnhem Land Expedition and the associated publicity. He led negotiations for funding and personnel with the Australian Minister to the United States, Sir Frederic Eggleston, in Washington, DC, the Secretary of the Smithsonian Institution, Alexander Wetmore, and staff of the National Geographic Society. ${ }^{17}$ As Wetmore wrote: 'We look forward with keen interest to this work, particularly to the close association that it brings between representatives of our two governments. We may, I trust, consider this a beginning to an even closer cooperation in future scientific matters than has existed heretofore. ${ }^{18}$ With the involvement of other institutions, including the Australian Museum and the Smithsonian Institution, the expedition Mountford had originally planned grew to 17 people and a diverse range of disciplines.

The Expedition was originally planned for 1947. The one-year delay was due to the Smithsonian Institution unexpectedly needing staff intended for the Arnhem Land Expedition for 'commitments in connection with the Bikini tests' ${ }^{19}$ In other words, the scientists intended for the Arnhem Land Expedition

17 Ibid., p. xxi; Mountford, 'Report on expedition for the National Geographic Society', p. 225.

18 Alexander Wetmore, 3 December 1947, Letter to Bridges, Accession File 178294, Smithsonian Institution Archives, Washington, DC, p. 3.

19 Arthur Calwell, 28 February 1947, Letter to J. J. Dedman, Series A 9816/4, 1947/89, Part 1, NADC, Arnhem Land Expedition, National Archives of Australia, Canberra. 
were required for research relating to nuclear weapons testing in the Pacific. Calwell felt that without the Americans, the Expedition would not achieve the desired publicity, so, with little consultation, he decided to delay for one year. This alone is evidence of the power Calwell had over this team and process. Yet the delay provided Mountford and his team with more time to prepare for their ambitious research and schedule. The Expedition team now included Mountford as leader and Smithsonian Institution archaeologist Frank Setzler as deputy leader. It also included a botanist, mammalogist, ichthyologist, ornithologist, anthropologist, photographer, cine-photographer, and a team of medical and nutritional scientists plus support staff. Together these men and women embarked on an amazing journey.

After leaving Darwin, the Expedition team set up its first base camp on Groote Eylandt in the Gulf of Carpentaria. Three months later, they moved to Yirrkala on the Gove Peninsula and three months following that to Oenpelli (now Gunbalanya) in Western Arnhem Land. Mountford states that he chose these camps because they represented different environmental regions and research would therefore produce diverse outcomes. He also chose a camp at the Roper River but this was abandoned due to delays in starting work on Groote Eylandt. ${ }^{20}$

After two weeks in Darwin waiting for their supplies to arrive overland from Adelaide, the team made its way to the first base camp, Umbakumba, on Groote Eylandt. Most of the team arrived aboard a RAAF Catalina flying-boat, however, a few team members decided to make the journey by sea and were stranded when a storm pushed the Phoenix onto a reef near the mouth of the Liverpool River. The barge was stuck on the reef for five weeks as the crew attempted to save Expedition equipment and food. One of the stranded Expedition members was National Geographic Society photographer Howell Walker, who later documented this journey in the article 'Cruise to Stone Age Arnhem Land' ${ }^{21}$ The media had a field day, as this article illustrates:

\section{Starving Scientists}

A Catalina left Darwin at daylight today with emergency supplies for the American-Australian Scientific Expedition on Groote Eylandt, as the launch which was to have followed the expedition with supplies broke down. Until the aeroplane arrives the scientists will have a firstclass chance of studying native food-stuffs. ${ }^{22}$

\footnotetext{
20 Mountford, Records of the American-Australian Scientific Expedition to Arnhem Land, vol. 1, p. xxiii; Mountford, 'Report on expedition for the National Geographic Society', p. 225.

21 Walker, H. 1949, 'Cruise to Stone Age Arnhem Land', National Geographic, vol. 96, no. 3, pp. 417-30.

22 'Starving scientists', Daily Mirror, 16 April 1948.
} 
Cameraman Peter Bassett-Smith was one of those waiting on Groote Eylandt and he clearly had a bit of time on his hands, as he managed to pen an epic song about the experience. He titled his song 'The Phoenix Never Came In' and the following is a sample of his work:

An expedition left the north one day,

Flew by Catalina far away,

All the stores were to have gone ahead

On the barge Phoenix, instead.

But the Phoenix never came in.

While on Groote Eylandt they were near starvin'

She hadn't even left Darwin.

Oh! The Phoenix never came in.

All was well on a clear blue sea,

Eggs for breakfast, caviar for tea!

Super service made the voyage fine,

On that Capricornian Line,

But the Phoenix never came in. ${ }^{23}$

Not to be outdone, Fred Gray also wrote a song, which he titled 'Shores of Umbukwumba':

From the shores of Umbukwumba to the great Ung-oo-roo-koo,

This place's so full of scientists, there's no room for me or you

They were eating lots of tucker, and sitting in their tents,

And waiting for the Phoenix in the cause of sci-i-ence. ${ }^{24}$

Mountford and his team had set up camp next to Fred Gray's so-called 'native settlement' at Umbakumba. Here Mountford thought he would have a better chance of becoming acquainted with the local people and access to facilities. ${ }^{25}$ Setzler later recorded that the younger Indigenous men were keen to assist the Expedition with tasks such as moving equipment but the older men 'preferred to wait and see what this white intrusion might signify' ${ }^{26}$ The memories of Gerry Blitner, recorded shortly before he passed away, are enlightening, as they provide an insight into the Indigenous experience of the Expedition. ${ }^{27}$ Gerry

23 This song is taken from the unpublished booklet of the fiftieth anniversary reunion of the Arnhem Land Expedition produced by and in the possession of Raymond Specht.

24 I have not reproduced the whole song here but rather just a selection. The full song is included in ibid.

25 Mountford, Records of the American-Australian Scientific Expedition to Arnhem Land, vol. 1, p. xxiii.

26 Frank Setzler, 13 January 1950, Lecture Notes, National Geographic Society presentation, Accession File 178294, Smithsonian Institution Archives, Washington, DC, p. 8.

27 M. Thomas, 2007, Gerald Blitner interviewed by Martin Thomas [sound recording], ID 4198706 (ORAL TRC 5851), National Library of Australia, Canberra; S. K. May, 2007, Gerald Blitner interviewed by Sally K. May [digital film recording], Research School of Humanities and the Arts, the Australian National University, Canberra. 
was an Indigenous assistant to the Expedition on Groote Eylandt and provided valuable insights into the activities and the concerns felt by local community members.

Margaret McArthur (nutritionist) arrived by air into Groote Eylandt and began her research immediately. She had successfully established a nutrition camp at Hemple Bay by the time the Phoenix arrived. McArthur would later also work with Expedition botanist, Raymond Specht, and Native Affairs officer Howard Coate on Bickerton Island. Her aim was to investigate the food-gathering techniques and nutrition of the local people while Specht concentrated on the botany of the area. ${ }^{28}$

Specht's diary also gives an interesting insight into camp life during the Expedition's time on Groote Eylandt. He writes:

Apart from two excellent cooks (helped by two Aborigines) who do wonders with tinned food, we have many other amenities. We each have a tent that serves as a laboratory as well... We have an open invitation to visit and use the Grays' homestead whenever we like. The Grays have put themselves out for us. They have even put electric light down to our mess tent, as well as water. Our work has definitely upset their routine; Fred Gray, in typical English style, doesn't deny it, but passes it off with a smile. His wife, Marjorie... appreciates the company. Her 'desert island disks' - gramophone records including 'I'm all so alone in a strange land'-haunts [sic] us at night. ${ }^{29}$

Another example of the work taking place includes the production of face casts by Frank Setzler. Setzler took plaster hand and face casts of people from the Umbakumba community using the Negaocol technique. These casts were intended to assist in producing life-size moulds of Australian Indigenous people to display in the Smithsonian Institution. His method was as follows:

After becoming acquainted with some of the men and observing their craving for tobacco, I was able to induce Kumbiala to undergo a warm mud bath treatment. This mulage had to be dissolved in a double boiler, then allowed to cool so as not to burn, but applied as warm as possible. The first coat was put on with a stiff brush in order to fill the pores... after removing the masks, the natives' faces, as you will probably notice, will be a shade lighter and their pores lose years of accumulated dirt. ${ }^{30}$

28 Mountford, Records of the American-Australian Scientific Expedition to Arnhem Land, vol. 1, p. xxv.

29 Raymond Specht, 22 April 1948, Arnhem Land Expedition field diary, in possession of Raymond Specht, Brisbane.

30 Setzler, Lecture Notes, p. 8. 
Some of these casts were made into bronze busts and are still held at the National Museum of Natural History in Washington, DC. Setzler also collected palm and fingerprints from more than 100 people. He undertook this work with the assistance of Bessie Mountford, the wife of the Expedition leader and honorary secretary for the team. He tested the tastebuds of the members of 60 families, collected hair samples, took photographs, collected artefacts, produced biological reports on Indigenous activities and took soil samples for pharmaceutical companies. ${ }^{31}$

While dozens of men and women assisted with the Expedition on Groote Eylandt, it was a man Mountford called Nangapiana who was singled out as an important assistant. Nangapiana was an artist and his work is represented in many collections that now exist from the Arnhem Land Expedition. ${ }^{32}$ Most of the Expedition members kept journals during their adventures and, as a result, we know the names (or the names that the Expedition members used) of some of the people who worked with the Expedition. ${ }^{33}$

The Expedition moved to its second base camp, Yirrkala, on Thursday, 8 July. Yirrkala was a Methodist Overseas Mission station at this time, having been established in 1935, and it was again decided to set up camp near these existing facilities. A few days after arriving at this base camp, Expedition members received a wireless message informing them that Arthur Robert Driver, Administrator of the Northern Territory, Elvin Seibert, US Consul from Adelaide, and Kevin Murphy, Deputy Administrator of the Department of Information would be landing near Yirrkala at 9.30 am with the intention of visiting their camp. ${ }^{34}$ Murphy and Driver requested a private audience with Mountford and Setzler and stated very clearly that the Department of Information was upset at the delays and poor transport arrangements they considered had been made by the leader to date. The result of this meeting was that Mountford was asked to relinquish leadership of the scientific aspects of the Expedition to Setzler and he was told to concentrate on producing films rather than undertaking anthropological research. Setzler was reluctant but did not immediately refuse the new position offered to him-something that Mountford found hard to forgive. ${ }^{35}$ Setzler considered the offer and the next day discussed it with his American colleagues, who quickly advised him to refuse. ${ }^{36}$ He sent a telegram

31 Frank Setzler, (n.d.), Memo to Mountford, Setzler Files, Box 7, Folder 2 of 2, p. 2, National Anthropological Archives, Washington, DC.

32 May, Collecting Cultures.

33 Ibid.

34 Frank Setzler, 12 July 1948, Letter to A. Wetmore, Accession File 178294, Smithsonian Institution Archives, Washington, DC.

35 Charles Mountford, 29 July 1948, Letter to A. Wetmore, Accession File 178294, Smithsonian Institution Archives, Washington, DC.

36 Frank Setzler, 12 July 1948, Letter to A. Wetmore, Accession File 178294, Smithsonian Institution Archives, Washington, DC. 
to Kevin Murphy informing him that it was simply impossible for him to accept the position. ${ }^{37}$ The fieldwork in Yirrkala was not off to a good start. There was, however, one good outcome from this meeting. Murphy arranged for Bill Harney to join the Expedition, stating, 'my only concern is that you and your colleagues be given ample opportunity for profitable scientific research. To this end [I] am sending [Bill] Harney as guide confident that his knowledge of terrain will give you what you want. ${ }^{\prime 38}$

So what did the researchers concentrate on during their time at Yirrkala? Mountford and McCarthy were working with, and collecting paintings from, artists such as Mawalan Marika, Wandjuk Marika and Narritjin Maymuru. While Mountford's collection of objects, and especially paintings, remained constant during the Expedition, his record keeping slowly deteriorated at Yirrkala and Oenpelli. The same methods of ethnographic collecting were undertaken throughout the Expedition and Mountford remained primarily around the base camp for the three months they were camped at Yirrkala.

It was a different story for other Expedition members, who scattered themselves around the islands and mainland sites of Arnhem Land. For example, McArthur, Miller, Setzler, McCarthy and Harney travelled to Port Bradshaw, where they conducted their independent research including archaeological excavations. McArthur established a nutrition camp with two Indigenous companionssomething that concerned Mountford greatly. McArthur claimed that she could get a truer picture of the local people in their natural environment if she was by herself, ${ }^{39}$ however Mountford did not think it was appropriate for a woman to be alone in Arnhem Land. Nevertheless, he gave her permission to go. ${ }^{40}$ Even as late as 1948, McArthur's ability to work independently in remote regions of Australia was considered daring and, to some, inappropriate for a woman, with one newspaper article labelling her 'gamer than Ned Kelly'. ${ }^{41}$

On their return from Port Bradshaw, Setzler and McCarthy travelled to Milingimbi Island to carry out archaeological research while the others concentrated their study around the camp. There was growing tension between some Expedition members by this stage, the worst of which appears to have been between Mountford and McCarthy. To give some idea of their feelings towards each other, I will offer this quote from McCarthy's diary: 'I told him [Mountford] that I was fed up with the bloody expedition on the basis of the constant jealousy of all the work that I was doing and the constant arguments about the number of and the distribution of the specimens. ${ }^{42}$

37 Ibid.

38 Kevin Murphy, 14 July 1948, Letter to Frank Setzler, Accession File 178294, Smithsonian Institution Archives, Washington, DC.

39 Mountford, Records of the American-Australian Scientific Expedition to Arnhem Land, vol. 1, p. xxvii.

40 Mountford, 'Report on expedition for the National Geographic Society', p. 229.

41 'Scientist "gamer" than Ned Kelly', Herald, 22 September 1948.

42 Frederick McCarthy, 18 July 1948, Entry in diary 4, MS3513 Box 22, Item 269, AIATSIS Library, Canberra. 
During their time on Milingimbi Island, Setzler and McCarthy undertook excavations and also collaborated to collect ethnographic artefacts. They seemed to prioritise their archaeological work but after they had finished each day they returned to their tent and began trading with whoever had brought materials to sell. McCarthy recorded that people were eager to trade and, as discussed by Hamby, ${ }^{43}$ the number of artefacts obtained over a three-week period was substantial. ${ }^{44}$

Back at Yirrkala, the team continued to work with large numbers of local people in areas ranging from general camp maintenance and painting to string figures and medical research. One person who stands out as a central figure is Mawalan Marika (also spelt Mauwalun or Moalun by Expedition members). Born in 1908, Mawalan Marika was a highly regarded leader of the Rirratjingu people of north-east Arnhem Land. He was a significant artist and is represented in many museum collections. Many works of Mawalan's family members are also represented in the Arnhem Land Expedition collection, including his son Wandjuk Marika. ${ }^{45}$

Yirrkala was a productive camp for the group and all Expedition members made large collections. Before moving to Oenpelli, most of the team was taken to Darwin for one week to secure their collections and restock their supplies. They arrived at their new camp by 20 September 1948 (Figure 9.4). ${ }^{46}$ Interestingly, on the way to Oenpelli, mammalogist David Johnson jumped ship at Cape Don and walked $260 \mathrm{~km}$ overland to Oenpelli (arriving on 19 October), on his way acquiring a significant collection of mammals for the Smithsonian Institution.

The final base camp for the Arnhem Land Expedition proved to be the hardest for most of the Expedition members. It was hot, the local mission did not really want them there, and the team members had been in the field for six months already. ${ }^{47}$ There is no doubting, however, that this final base camp provided some of the most important scientific findings of the Expedition. The group set up camp at the edge of the Oenpelli billabong, surrounded by a dramatic landscape of rocky outliers and with the Arnhem Land Escarpment in the distance.

\footnotetext{
43 Hamby, this volume.

44 Frederick McCarthy, (n.d.), Report on scientific work, Series 10 1927-1956, 22/1948, p. 8, Australian Museum Archives, Sydney.

45 May, Collecting Cultures.

46 Setzler, Lecture Notes, p. 28.

47 May, Collecting Cultures.
} 


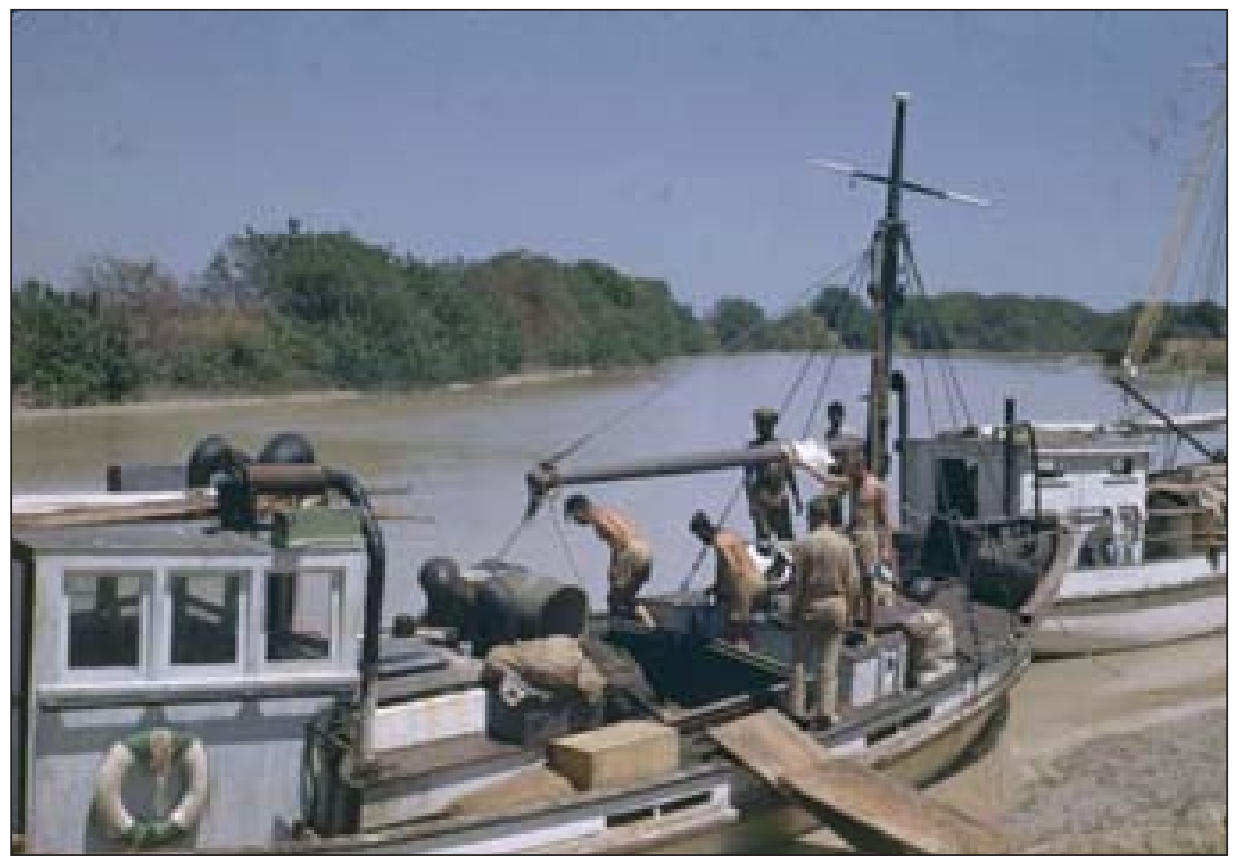

Figure 9.4 Phantom and Victory being unloaded at Oenpelli Landing, 20 September 1948

Photograph by Robert Rush Miller. By permission of the National Library of Australia. nla.pic-vn4514017.

The township of Oenpelli sits in country belonging to the Mangerridji people, and, in 1948, it was a Church Missionary Society settlement with a history that included life as a buffalo shooting camp. In 1948, most of the Expedition members remained in or very near to Oenpelli throughout the three months they were conducting their research. Some Expedition members (including Howell Walker, Peter Bassett-Smith and Raymond Specht) suggested to me that at Oenpelli they had the least amount of contact with local people. This was due in part to the mission being unwilling to spare people from their normal jobs. ${ }^{48}$

The traditional owner of this region at the time of the Expedition was a man by the name of Nipper Marakara (Figure 9.5). During his remarkable life, he oversaw the movement of Paddy Cahill into this region in the early 1900s, and the establishment of the church in Oenpelli in 1925; he worked with Baldwin Spencer and Ronald and Catherine Berndt, and was still active when Mountford and his team turned up in 1948. Very little has been written on this important Indigenous leader and artist. Mountford records this traditional owner's name as Kumutun in his records from the Arnhem Land Expedition and also mentions 
three artists by the names of Larida, Willirra and Wulkini. Visiting ABC journalist Colin Simpson reflected on the situation at Oenpelli in 1948 with the following statement:

The old men Mountford brought back to the tent had been hoeing the mission's melon patch. They looked unimpressive, they looked dreadful in cast-offs of clothing and shapeless relics of felt hats. They sat down on the grass, folding themselves down in that slow and diffident way they have with white men, one wringing his nose out with his fingers, another coughing. I thought to myself, 'Nothing much can come of this'. I was judging on appearances, presuming that the old men had shed their validity as aborigines and put off their old culture because they had put on rags of white-man clothing and were taking hand-outs from the mission.

It was these old men and others they mustered who, transformed with paint and fervour, gave us the unforgettable performance of the... corroboree a few days later. ${ }^{49}$

Herbert Deignan, Robert Miller and Raymond Specht were probably more excited about Oenpelli than any of the other researchers, as there they found abundant and diverse birds, fish and plants for their work and made some important discoveries. Miller claimed that the waterways surrounding Oenpelli were the richest he had ever fished and Specht discovered several new species of plants. ${ }^{50}$

During the time in Oenpelli, conditions were not ideal for medical research and the intense heat and the dust were a continuous trial. ${ }^{51}$ As well as working with Setzler on archaeological excavations, McCarthy travelled with McArthur and John Bray to Fish Creek where they undertook an influential study of food gathering (see Altman, this volume). ${ }^{52}$

The fieldwork component of the Arnhem Land Expedition officially came to a conclusion in early November 1948, with a barge transporting the collections and the team members back to Darwin along the East Alligator River. ${ }^{53}$

\footnotetext{
49 Simpson, Adam in Ochre, pp. 6-7.

50 Mountford, 'Report on expedition for the National Geographic Society', p. 230.

51 Ibid.

52 McCarthy, F. and McArthur, M. 1960, 'The food quest and the time factor in Aboriginal economic life', in C. P. Mountford (ed.), Records of the American-Australian Scientific Expedition to Arnhem Land. Volume 2: Anthropology and nutrition, Melbourne University Press, Carlton, Vic., pp. 145-94.

53 Mountford, Records of the American-Australian Scientific Expedition to Arnhem Land, vol. 1, p. xxix-xxx.
} 


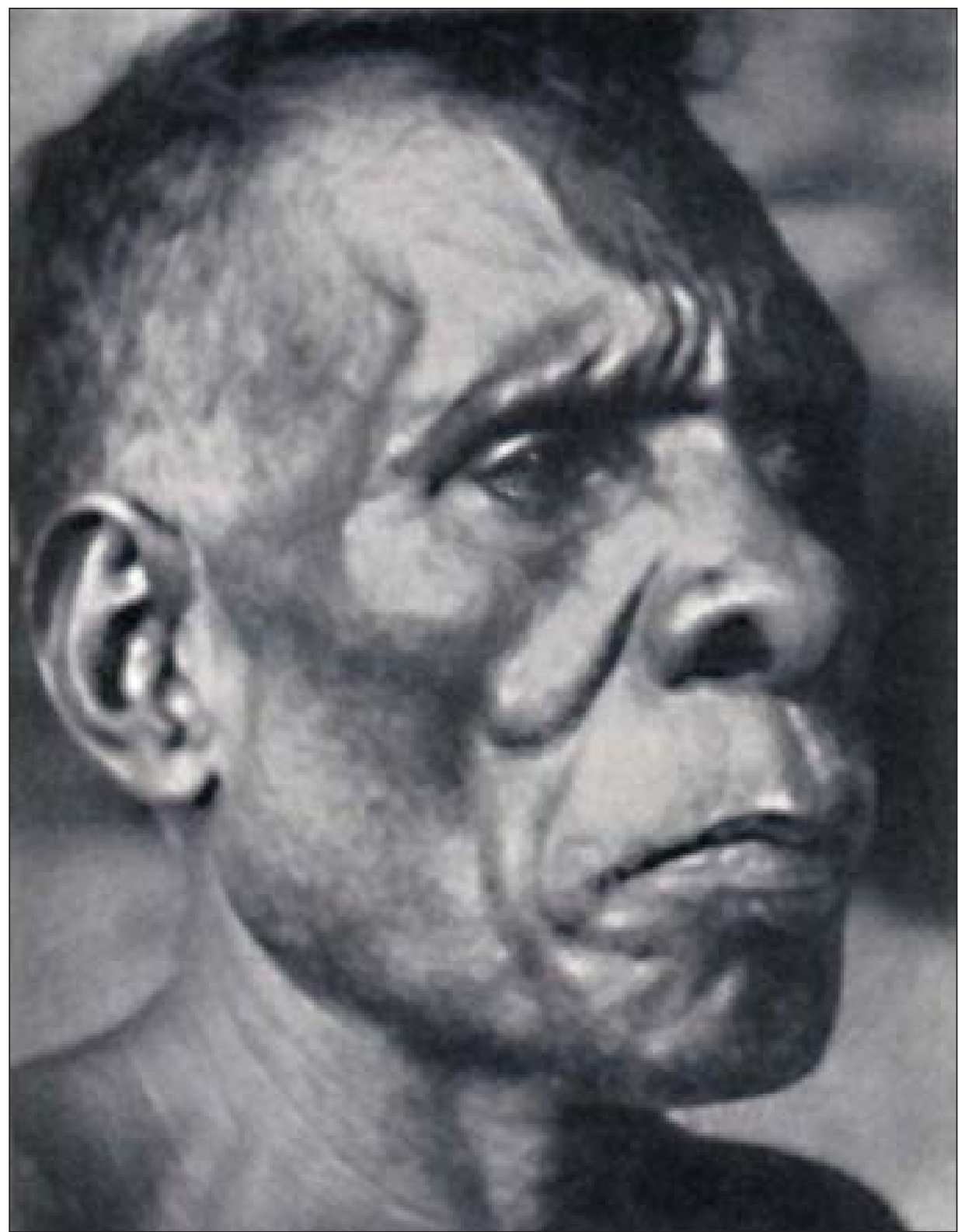

Figure 9.5 Portrait of Nipper Marakara (Kumutun) from Oenpelli (now Gunbalunya)

Photograph by Charles P. Mountford. From Charles P. Mountford (ed.) 1956, Records of the American-Australian Scientific Expedition to Arnhem Land. Volume 1: Art, myth and symbolism, Melbourne University Press, Carlton, Vic. 
Rumours had leaked to the press that all was not well among the Expedition members, and as it began to reach its conclusion Mountford realised that in order to protect the reputation of the Expedition (and its stakeholders) he would need to ask his team to present a united front. He wrote to Alexander Wetmore on 5 November 1948, stating that he was afraid his letters might have created a wrong impression and that the camp was actually a very harmonious one. He claimed that he had not heard of a single argument between any of the members. ${ }^{54}$ At the same time, he requested that Setzler not be allowed anywhere near the Australian ministerial or departmental heads for fear that he would not be discreet. Wetmore was receiving letters from many of the Expedition members and was probably better informed about problems in the camp than many of the people in the field. For example, the Expedition ornithologist, Herbert Deignan, wrote to him in August stating that Mountford wanted all of the party to arrive together in Adelaide at the end because of the Expedition's recent troubles. ${ }^{55}$ After managing to direct an extended Expedition, Mountford now had to fight for his reputation, his legacy and his job.

This was clearly a politically complex and logistically daunting Expedition and Mountford's sacrifices to make it happen were extreme. On top of the pressure placed upon the leader from the government came the responsibility of satisfying museums in Australia and in the United States, as well as the National Geographic Society and individual members of the team. Eventually, these worries took their toll on Mountford's health and he suffered fainting spells. Setzler commented that 'our main hope now is to hold him down from worry and exhaustion, so that we can all safely return to Darwin' ${ }^{56}$

There are many aspects of this Expedition that I have not touched upon. These include the relationships that were formed between particular Expedition members who continued to correspond for decades and the encouragement that McArthur received from many of her colleagues to continue and expand her research. I have also not touched upon the fact that some of the work undertaken in 1948 today causes distress for Indigenous communities. ${ }^{57}$ This includes the removal of human skeletal remains from their place of rest without the permission of local community members (Figure 9.6). I have argued elsewhere that the people in the Aboriginal communities visited were recorded alongside

\footnotetext{
54 Charles Mountford, 5 November 1948, Letter to A. Wetmore, Accession File 178294, Smithsonian Institution Archives, Washington, DC.

55 Herbert Deignan, 26 August 1948, Letter to A. Wetmore, Accession File 178294, Smithsonian Institution Archives, Washington, DC.

56 Frank Setzler, 6 October 1948, Letter to A. Wetmore, Accession File 178294, p. 2, Smithsonian Institution Archives, Washington, DC.

57 May, S. K. with Gumurdul, D., Manakgu, J., Maralngurra, G. and Nawirridj, W. 2005, “'You write it down and bring it back...that's what we want" - revisiting the 1948 removal of human remains from Gunbalanya 
the flora and fauna of the region. ${ }^{58}$ They were photographed, their movements recorded, their artefacts collected, and the findings published primarily for the benefit of non-Indigenous people.

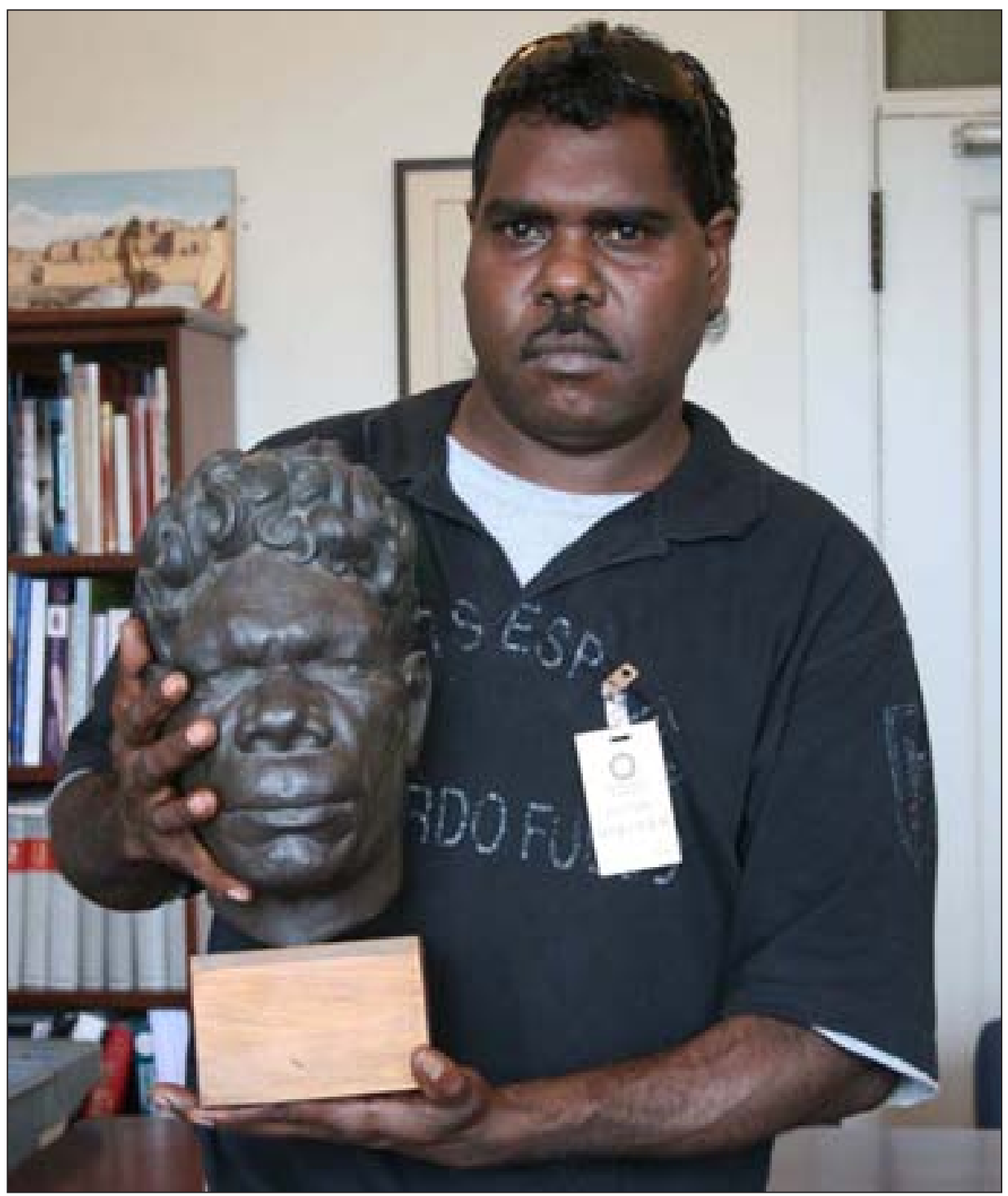

Figure 9.6 Thomas Amagula of Groote Eylandt at the Smithsonian Institution holding a bronze bust of one of his relatives, produced from a face cast taken in 1948 by Frank Setzler, 2008

Photograph by Sally K. May 
To a large extent, Indigenous people were caught up in a game being played by the Commonwealth of Australia. They were used to further political and social goals. The impact upon local communities appears not to have been considered. Yet, Indigenous community members were not simply victims of this political game. The Expedition provided a unique opportunity for trade, employment and skills acquisition. The wish for an ethnographic collection placed these communities in a situation of power and they made the most of these opportunities, gaining money, food and goods in return for services. Some community members had the opportunity to work with internationally renowned experts and learnt skills associated with their disciplines (such as botany, archaeology and medical science).

Today it is essential that museums consult with the communities visited by the Arnhem Land Expedition to contextualise their collections. The lack of Indigenous voices in the records and documentation of this Expedition must be addressed. In keeping these artefacts, institutions have entered into a contract of engagement with Arnhem Land communities - something that can be of benefit to both parties. 